\title{
Hubungan Antara Kompetensi Profesional Guru dengan Hasil Belajar Peserta Didik Madrasah Aliyah Subulussalam 2 OKU Timur
}

\author{
Effendi ${ }^{*}$, dan Nila Nuryana \\ Program Studi Pendidikan Fisika STKIP Nurul Huda Sukaraja, \\ Jalan Kotabaru Sukaraja, Buay Madang, OKU Timur, Sumatera Selatan Selatan \\ ‘E-mail: effendi@stkipnurulhuda.ac.id
}

\begin{abstract}
ABSTRAK
Penelitian ini bertujuan untuk mengetahui hubungan antara kompetensi profesional guru dengan hasil belajar peserta didik MA Subulussalam 2 OKU Timur. Metode penelitian yang digunakan yakni kuantitatif korelasi yang bersifat kausal (sebab akibat). Populasi penelitian ini adalah seluruh peserta didik MA Subulussalam 2 OKU Timur. Pengambilan sampel dilakukan dengan cara acak, dengan jumlah sampel sebanyak 30. Dalam penelitian ini terdapat dua variabel yaitu: variabel $(\mathrm{X})$ adalah kompetensi profesional guru dan variabel $(\mathrm{Y})$ adalah hasil belajar peserta didik. Data variabel $X$ diperoleh dengan penyebaran angket, sedangkan variabel $Y$ diperoleh dengan uji tes soal pilihan ganda. Data angket diperoleh nilai rata-rata 87,8 dari skor maksium 101 sedangkan nilai rata-rata tes 70,13 dari nilai maksimum 90 . Dari data tersebut diolah dengan menggunakan rumus korelasi Product Moment. Dari hasil pengolahan data tersebut diperoleh bahwa nilai rxy sebesar 0,79 . Sedangkan $t$ tabel sebesar 2,048 pada $\mathrm{N}=28$ dengan taraf signifikan $5 \%$ dan t hitung 6,82. Hal ini berarti bahwa t hitung $>\mathrm{t}$ tabel $(6,82>2,048)$ Ha diterima sedangkan Ho nya ditolak. Dari data tersebut dapat disimpulkan bahwa terdapat hubungan yang signifikan antara kompetensi profesional guru dengan hasil belajar peserta didik MA Subulussalam 2 OKU Timur.
\end{abstract}

Kata Kunci:Kompetensi Profesional Guru, Hasil Belajar Peserta Didik

\begin{abstract}
This study aims to determine the relationship between teacher professional competence and students' learning outcomes of Madrasah Aliyah Subulussalam 2 East OKU. The research method used was quantitative causal correlations (cause and effect). The population of the study was all students of Madrasah Aliyah Subulussalam 2 East OKU. Sampling was done by using random method, with a total sample was 30 students. In this study there were two variables: variable $(X)$ was the teacher's professional competence and variable $(Y)$ was the students' learning outcomes. Variable $X$ data was obtained by distributing questionnaires, while $Y$ variable was obtained by multiple choice test questions. The questionnaire data obtained an average value was 87.8 from a maximum score was 101 while the average value of the test was 70.13 from a maximum value was 90 . From the data, it was processed by using the Product Moment correlation formula. From the results of data processing, it was obtained that the rxy value was 0.79 . While $t$ table was 2.048 at $N=28$ with a significant level of $5 \%$ and $t$ obtained was 6.82. This means that $t$-obtained $>t$ table $(6.82>2,048) \mathrm{Ha}$ is accepted while Ho was rejected. From these data it can be concluded that there is a significant relationship between teacher professional competence and students' learning outcomes of Madrasah Aliyah Subulussalam 2 East OKU.
\end{abstract}

Keywords: Teacher Professional Competence, Students' Learning Outcomes 


\section{PENDAHULUAN}

Pendidikan merupakan sebuah proses (Ernawati dan Effendi, 2017). Proses tersebut dimaksudkan sebagai upaya dalam mencapai tujuan pendidikan. Sebab pendidikan merupakan salah satu cara yang strategis bagi peningkatan mutu sumber daya manusia (SDM). Guru sebagai tenaga profesional mempunyai fungsi, peran, dan kedudukan yang sangat penting dalam mencapai visi pendidikan nasional yaitu menciptakan insan Indonesia cerdas dan kompetitif. Guru harus mengembangkan profesinya sebagai profesi yang bermartabat (Noorjannah, 2015). Sehingga proses pertolongan yang terus menerus dari penyesuaian yang lebih tinggi bagi manusia yang telah berkembang secara fisik dan mental yang pada akhirnya akan mampu menggapai hasil yang diharapkannya (Effendi dan Pantriani, 2020). Hasil belajar merupakan tolak ukur keberhasilan peserta didik dalam mempelajari materi yang disampaikan selama periode tertentu. Untuk mengetahui hasil belajar peserta didik guru perlu mengadakan evaluasi atas kemampuan peserta didik saat memahami materi yang telah disampaikan. Tujuan proses pembelajaran di sekolah adalah bahwa semua peserta didik dapat memperoleh hasil belajar yang maksimal. Menurut Syarif (2013) "Hasil belajar merupakan perubahan perilaku yang diperoleh peserta didik setelah mengalami kegiatan belajar". Dengan demikian hasil belajar merupakan hal penting untuk mengetahui apakah tujuan pendidikan sudah tercapai secara optimal.

UU Nomor 20 Pasal 1 ayat (6) Tahun 2003 dinyatakan bahwa pendidik adalah tenaga kependidikan yang berkualifikasi sebagai guru, dosen, konselor, pamong belajar, widyaiswara, tutor, instruktur, fasilitator, dan sebutan lain yang sesuai dengan kekhususannya, serta berpartisipasi dalam menyelenggarakan pendidikan. Gurumerupakan ujung tombak dalam meningkatkan kualitas pendidikan. Terutama dalam memberikan motivasi kepada siswa sehingga mampu meningkatkan kualitas pendidikan demi mencerdaskan kehidupan bangsa (Idzhar, 2016). Namun demikian guru harus memiliki kompetensi yang cukup. Kompetensi merupakan kemampuan yang harus dimiliki oleh seorang guru dalam melaksanakan tugas mengajarnya. kompetensi guru merupakan kemampuan dan kewenangan guru dalam melaksanakan profesi keguruannya (Araniri, 2018). Menjadi guru profesional bukan hal yang mudah, banyak guru yang belum profesional dalam melaksanakan pembelajarannya di kelas. Terlebih pendidikan di abad ini menuntut adanya manajemen pendidikan yang modern dan guru profesional (Danil, 2017). Pola pendidikan yang baik memicu serta mempengaruhi pada hasil belajar peserta didik. Karena hasil belajar merupakan tolak ukur keberhasilan peserta didik selama belajar, sedangkan guru yang profesional merupakan tolak ukur bagi seorang guru atas keberhasilannya dalam menyampaikan materi pembelajarannya di kelas. Intensitas pengalaman belajar dapat dilihat dari tingginya keterlibatan pelajar dalam hubungan belajar mengajarnya dengan guru dan obyek belajar (Saragih, 2008)

Selain itu, pentingnya menjadi guru profesional ditengah-tengah para peserta didik adalah yang mampu mencairkan suasana kejenuhan, kebosanan sehingga membuat pembelajaran berjalan dengan semestinya dan materi mampu diterima oleh peserta didik. Oleh karena itu sangat perlu seorang guru belajar atau mempelajari untuk menjadi guru yang profesional. Guru sebagai tenaga profesional mempunyai fungsi, peran, dan kedudukan yang sangat penting dalam mencapai visi pendidikan nasional yaitu menciptakan insan Indonesia cerdas dan kompetitif. Guru harus mengembangkan profesinya sebagai profesi yang bermartabat (Noorjanah, 2014).

Berdasarkan Undang-Undang No.14 tahun 2005 tentang Guru dan Dosen (UUGD) pasal 10 ayat 1 menyebutkan bahwa ciri-ciri guru profesional adalah mempunyai kompetensi sebagai berikut yaitu : kompetensi profesional, kompetensi pedagogik, kompetensi kepribadian dan kompetensi sosial". Ismail (2010) kompetensi adalah kemampuan, kecakapan, keterampilan, dan 
pengetahuan seseorang di bidang tertentu. perkembangan era globalisasi yang demikian pesat, perubahan yang sangat cepat dan berkelanjutan dibidang teknologi informasi menuntut seorang guru untuk profesional dalam menguasai materi yang akan diberikan (Sunandar dan Effendi, 2015). Dari penjelasan tersebut jelas bahwa kompetensi profesional guru itu sangat penting dalam proses pembelajaran serta akan mempengaruhi pada keberhasilan pembelajaran peserta didik. Sebab profesionalisme guru merupakan kondisi, arah, nilai, tujuan dan kualitas suatu keahlian dan kewenangan dalam bidang pendidikan dan pengajaran (Misnawati, 2017).

\section{METODE PENELITIAN}

Penelitian ini menggunakan desain korelasi yang bersifat kausal (hubungan yang bersifat sebab akibat) yaitu peristiwa yang terjadi karena adanya sebab dan akibat. Teknik pengambilan sampel dalam penelitian ini dilakukan dengan acak dan yang terpilih adalah klas X IPA. Teknik pengumpulan data penelitian ini menggunakan angket dan tes. Metode angket yang diberikan berupa daftar cek (checklist). Metode angket merupakan serangkaian atau daftar pertanyaan yang disusun secara sistematis, kemudian dikirim untuk diisi oleh responden. Setelah diisi, angket dikirim kembali atau dikembalikan ke petugas atau peneliti (Fahdini dkk, 2014). Angket digunakan untuk mengukur kompetensi profesional guru sedangkan tesnya digunakan untuk mengukur hasil belajar peserta didik. Sebelum digunakan untuk pengumpulan data, instrumen tersebut di uji terlebih dahulu validitas dan reliabilitasnya, sehingga instrumen yang digunakan benar-benar instrumen yang handal.

Setelah data hasil penelitian didapatkan, peneliti melaksanakan beberapa langkah kegiatan analisis data yakni: menghitung ratarata, standard deviasi, mencari kategori tinggi sedang dan rendah. Selanjutnya dilakukan pengujian hipotesis dengan menggunakan uji t.

\section{HASIL DAN PEMBAHASAN}

Variabel kompetensi profesional guru masuk dalam kategori sedang sebesar $70 \%$ dengan frekuensi 21 responden. Presentasi interval distribusi data kompetensi profesional guru terbesar terdapat pada kelas interval 86-88 sebesar $40 \%$. Presentasi interval distribusi data kompetensi profesional guru terkecil terdapat pada kelas interval 92-97 sebesar $6,7 \%$. Variabel hasil belajar masuk dalam kategori sedang sebesar $53,3 \%$ dengan frekuensi 16 siswa. Presentasi interval distribusi data hasil belajar terbesar terdapat pada kelas interval 50-56 dan 60-74 sebesar $20 \%$. Presentasi interval distribusi data hasil belajar terkecil terdapat pada kelas interval 57 63 sebesar 6,7\%. Hasil dan pembahasan dipaparkan dengan panjang $60-70 \%$ dari panjang artikel. Hasil dari perhitungan analisis koefisien korelasi diperoleh sebesar 0,83. Jika diinterpretasikan dengan tabel $r$, harga $r$ tersebut menunjukkan bahwa terdapat hubungan yang sangat tinggi antara variabel $X$ dengan variabel $Y$, di mana $0,83<r<1,00$. Adapun hasil perhitungan analisis regresi diperoleh harga $\alpha=20,54$ dan harga $b=1,05$ sehingga persamaan regresinya adalah $\hat{Y}=$ $1,05 X+20,54$

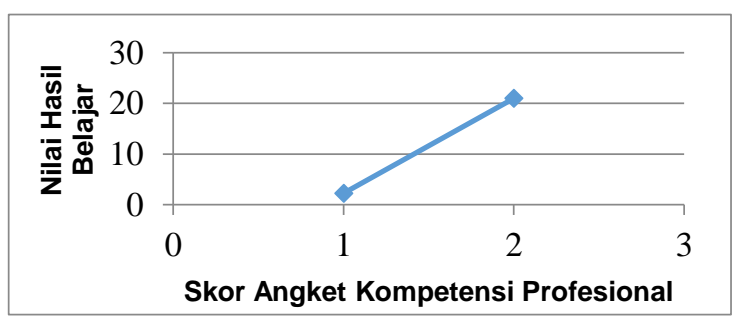

Gambar 1. Grafik persamaan regresi linear antara $x$ dan $y$

Berdasarkan grafik persamaan regresi linear sederhana di atas, dapat terlihat bahwa variabel-variabel tersebut memiliki hubungan yang positif. Titik pada garis tersebut mengarah dari kiri ke kanan atas. Uji hipotesis penelitian ini menggunakan uji t. Berdasarkan perhitungan hipotesis diperoleh $t_{\text {tabel }}=2,048$ pada taraf signifikansi $5 \%$ sedangkan $t_{\text {hitung }}=$ 7,88 . 


\section{PEMBAHASAN}

Setelah dilakukan analisis dan kajian secara mendalam, hasil pemberian angket yang dilakukan memberikan keterangan bahwa dari 30 peserta didik, terdapat 4 (13\%) peserta didik yang menjawab kompetensi dengan kategori tinggi, kemudian terdapat 21 $(70 \%)$ peserta didik yang menjawab kompetensi dengan kategori sedang dan 5 (17\%) peserta didik menjawab kompetensi dengan kategori rendah. Sedangkan hasil dari pemberian tes hasil belajar termasuk dalam kategori sedang. Hal ini dilihat dari nilai ratarata perolehan nilai hasil belajar 72,13 dari skor maksimum 100. Hasil tersebut dapat dilihat pada kategorisasi hasil belajar. Terdapat $8(26,75 \%)$ peserta didik masuk ke dalam kategori tinggi, 16 (53,3\%) peserta didik termasuk ke dalam kategori sedang, dan 6 $(20 \%)$ peserta didik termasuk ke dalam kategori rendah.

Berdasarkan analisis koefisien korelasi antara data kompetensi guru dan hasil belajar siswa dengan menggunakan rumus korelasi product moment Karl Pearson diperoleh nilai $r$ sebesar 0,83 . Harga $r$ tersebut menunjukkan bahwa terdapat hubungan yang sangat tinggi antara kompetensi profesional guru dengan hasil belajar peserta didik. Dari harga $r$ tersebut didapatkan nilai $K P$ sebesar $68,89 \%$. Nilai $K P$ tersebut menunjukkan bahwa $31,11 \%$ kompetensi profesional guru dapat hubungan yang signifikan dengan hasil belajar peserta didik, sedangkan 37,59\% terdapat faktor-faktor yang lain. Hasil perolehan dari analisis korelasi dan koefisien penentu tersebut, selanjutnya dilakukan analisis regresi dengan persamaan $\hat{Y}=1,05 X$ $+20,54$. Nilai $b$ pada persamaan tersebut bernilai positif sehingga garis persamaan regresi mengarah dari kiri ke kanan atas. Hasil penelitian ini sejalan dengan penelitian Anggela (2014) yang menyatakan bahwa (1) terdapat hubungan yang positif dan signifikan antara Kompetensi Profesional Guru dengan Prestasi Belajar Geografi Siswa SMA di Kota Yogyakarta dengan Koefisien korelasi antara $X 1$ dan $Y$ sebesar 0,4832, (2) terdapat hubungan yang positif antara Motivasi Kerja Guru dengan Prestasi Belajar. Selanjutnya penelitian Werdayanti (2008) menunjukkan bahwa ada pengaruh antara kompetensi guru dalam proses belajar mengajar di kelas dan fasilitas belajar terhadap motivasi belajar siswa. Dengan demikian sangat jelas sekali bahwa kompetensi profesional guru sangat berkaitan erat dengan hasil belajar yang diperoleh siswa. Oleh karena itu seorang guru harus senantiasa berupaya untuk senantiasa meningkatkan kualitas mengajarnya sehingga benar benar akan menjadi guru yang profesional. Bahkan Hayati (2016) menyatakan bahwa kompetensi profesional guru dengan hasil belajar siswa merupakan dua hal yang saling berhubungan, sebab kompetensi profesional yang dimiliki guru mampu menentukan hasil belajar yang diperoleh siswa. Menurut Dudung (2018) Peningkatan kompetensi tersebut dapat dilakukan dengan (1) melibatkan perguruan tinggi dalam penguatan kompetensi profesional; (2) memberdayakan forum guru dalam bidang mata pelajaran; (3) mengembangkan kapasitas pengawas sekolah/mata pelajaran yang bertugas membina kemampuan profesional para guru; (4) memperkuat dan mengintensifkan peran Pusat Pelatihan dan Pengembangan Guru (PPPG) sesuai rumpun bidang ilmu; (5) menyelenggarakan kegiatan workshop atau pelatihan intensif untuk mematangkan penguasaan materi ajar para guru; dan (6) memberikan beasiswa studi lanjut bagi para guru.

\section{PENUTUP}

Setelah dilakukan penelitian dan kajian serta analisis yang mendalam, peneliti berkesimpulan bahwa terdapat hubungan yang signifikan antara kompetensi profesional guru dengan hasil belajar peserta didik Madrasah Aliyah Subulussalam. Hal ini dibuktikan dengan hasil pengujian hipotesis diperoleh $t_{\text {tabel }}=2,048$ pada taraf signifikansi $5 \%$ sedangkan $t_{\text {hitung }}=7,88$. Sehingga $\mathrm{Ha}$ diterima dan Ho ditolak.

\section{UCAPAN TERIMAKASIH}

Rasa terimakasih diucapkan kepada Almamater Sekolah Tinggi Keguruan dan IImu Pendidikan Nurul Huda Sukaraja yang telah mengizinkan atas keterlaksanaan kegiatan penelitian ini hingga selesai. 


\section{REFERENSI}

Anggela, R. (2014). Hubungan antara Kompetensi Profesional Guru dan Motivasi Kerja Guru dengan Prestasi Belajar Geografi Siswa SMA di Kota Yogyakarta Tahun Ajaran 2012/2013. Doctoral dissertation, UNS (Sebelas Maret University).

Araniri, N. (2018). Kompetensi Profesional Guru Agama dalam Menumbuhkan Minat Belajar Siswa. Risâlah, Jurnal Pendidikan dan Studi Islam, 4(1), 75-83.

Danil, D. (2017). Upaya Profesionalisme Guru dalam Meningkatkan Prestasi Siswa di Sekolah (Study Deskriptif Lapangan di Sekolah Madrasah Aliyah Cilawu Garut). Jurnal Pendidikan UNIGA, 3(1), 30-40.

Dudung, A. (2018). Kompetensi Profesional Guru. Jurnal Kesejahteraan Keluarga dan Pendidikan, 5(1), 9-19.

Effendi, E., \& Pantriani, D. (2020). Penerapan Model Pembelajaran Generatif Pada Materi Usaha dan Pesawat Sederhana Kelas VIII MTs Nurussalam Sidogede OKU Timur. Physics Education Research Journal, 2(1), 59-67.

Ernawati, E., \& Effendi, E. (2017). Penerapan Lesson Study pada Pembelajaran Fisika Materi Perubahan Wujud Zat. JIPFRI (Jurnal Inovasi Pendidikan Fisika Dan Riset IImiah), 1(2), 41- 46.

Fahdini, R., Mulyadi, E., Suhandani, D., \& Julia, J. (2014). Identifikasi Kompetensi Guru sebagai Cerminan Profesionalisme Tenaga Pendidik di Kabupaten Sumedang. Mimbar Sekolah Dasar, 1(1), 3342.

Hayati, M. (2017). Hubungan antara kompetensi profesional guru dengan hasil belajar siswa mata pelajaran akidah akhlak kelas VIII MTs. Assa'adah Labuapi Tahun Pelajaran 2016/2017. Doctoral dissertation, Universitas Islam Negeri Mataram.

Idzhar, A. (2016). Peranan Guru dalam Meningkatkan Motivasi Belajar Siswa. Jurnal office, 2(2), 221-228.

Ismail, M. I. (2010). Kinerja dan kompetensi guru dalam pembelajaran. Lentera Pendidikan: Jurnal IImu Tarbiyah dan
Keguruan, 13(1), 44-63.

Misnawati, M. (2017). Hubungan Antara Kompetensi Profesional Guru Dengan Hasil Belajar Siswa Mata Pelajaran Aqidah Akhlak Di Madrasah Ibtidaiyah Negeri 1 Bandar Lampung. Doctoral dissertation, UIN Raden Intan Lampung.

Noorjannah, L. (2015). Pengembangan Profesionalisme Guru melalui Penulisan Karya Tulis IImiah Bagi Guru Profesional di SMA Negeri 1 Kauman Kabupaten Tulungagung. Jurnal Humanity, 10(1).

Syarif. 2013.Pengaruh Kompetensi Profesional Guru Dan Fasilitas Belajar Terhadap Hasil Belajar Siswa. Semarang: Fakultas Ekonomi Universitas Negeri.

Sunandar, D., \& Effendi, E. (2018). Penerapan Metode Brainstorming pada Pembelajaran Fisika Materi Wujud Zat. JIPFRI (Jurnal Inovasi Pendidikan Fisika Dan Riset IImiah), 2(1), 38-42.

Saragih, A. H. (2008). Kompetensi minimal seorang guru dalam mengajar. Jurnal Tabularasa, 5(1), 23-34.

Werdayanti, A. (2008). Pengaruh Kompetensi Guru dalam Proses Belajar Mengajar di Kelas dan Fasilitas Guru Terhadap Motivasi Belajar Siswa. Dinamika Pendidikan, 3(1). 